\title{
Reduksi Kandungan COD dan BOD pada Limbah Cair Batik menggunakan Metode Fitoremidiasi
}

\author{
Desi Erlita ${ }^{1)^{*}}$, MRS Darmanijati ${ }^{2}$, Siam Munandar ${ }^{3)}$ \\ Fakultas Teknologi Industri, Institut Teknologi Yogyakarta, Indonesia \\ desierlita@ity.ac.id, darmanijatimaria@gmail.com, siammunandar1@gmail.com
}

\begin{tabular}{l}
\hline open \\
access \\
*Penulis Korespondensi \\
\hline Histori Artikel: \\
Submit: 2022-01-21 \\
Diterima: 2022-01-24 \\
Dipublikasikan: 2022-02-01 \\
Kata Kunci: Enceng gondok; \\
Batik; cair; \\
Fitoremidiasi; Limbah \\
Wetland \\
\hline
\end{tabular}

\begin{abstract}
ABSTRAK
Limbah cair banyak dihasilkan pada industri batik pada proses pewarnaan. Penggunaan bahan pewarna sintetis pada proses pewarnaan menyebabkan limbah cair memiliki kandungan Biochemical Oxygen Demand (BOD) dan Chemical Oxygen Demand (COD) yang tinggi. Tujuan dari penelitian ini untuk mengetahui kinerja dari tanaman enceng gondok dalam mereduksi atau menurunkan kandungan COD dan BOD dalam limbah cair industri batik dengan metode fitoremidiasi. sehingga aman dibuang ke lingkungan. Fitoremidiasi menggunakan constructed wetland merupakan metode yang murah dibandingkan dengan metode yang lain.

Penelitian ini dilakukan secara eksperimental menggunakan constructed wetland dibantu tanaman enceng gondok dengan variable variasi jumlah limbah cair dan variasi waktu fitoremidiasi. Tahapan penelitian diawali dengan proses pembuatan wetland dengan tipe aliran atas permukaan dan pengukuran kadar COD dan BOD awal pada limbah cair batik. Setelah itu dilakukan proses aklimatisasi tanaman enceng gondok dan kemudian proses fitoremidiasi pada hari ke 1, 2, 3, 4, 5, 6, dan 7. Pengukuran kandungan COD dan BOD limbah cair batik dilakukan setiap hari.

Dari hasil uji laboratorium menunjukkan bahwa proses fitoremidiasi dengan tanaman enceng gondok bekerja efektif. Kandungan COD dan BOD awal pada limbah cair batik berturut-turut adalah $2.000 \mathrm{mg} / \mathrm{L}$ dan $1.020 \mathrm{mg} / \mathrm{L}$. Kadar yang sangat tinggi dan berbahaya untuk dibuang ke lingkungan. Setelah mendapatkan perlakuan terjadi penurunan kandungan COD dan BOD pada limbah cair batik. Efisiensi penurunan kandungan COD sebesar $62 \%$ dan BOD 69\%, sehingga metode ini diharapkan dapat diterapkan pada pengrajin atau industri batik.
\end{abstract}

Jurnal Pendidikan Sains dan

Komputer is licensed under a

Creative Commons Attribution-

NonCommercial 4.0 International

(CC BY-NC 4.0).

\section{LATAR BELAKANG}

Industri batik di Indonesia berkembang pesat dan memberikan dampak positif. Diantaranya dapat melestarikan budaya daerah dan menciptakan lapangan pekerjaan. Kota Yogyakarta, yang merupakan salah satu kota penghasil kerajinan batik terbesar di Indonesia. Namun ternyata, ada dampak negatif dengan semakin pesatnya industri batik yaitu limbah cair yang banyak dihasilkan dari proses pewarnaan. Menurut (Badan Pusat Statistik, 2018) sungai-sungai yang berada di Provinsi Daerah Istimewa Yogyakarta status mutu air tergolong tercemar berat [1]. Pengetahuan sejumlah pengrajin pada industry batik untuk pengelolaan limbah cair batik yang relatif rendah sehingga hanya membuang limbah tersebut ke badan sungai,. Hal tersebut menyebabkan pencemaran pada air sungai dan pada akhirnya menurunkan kualitas air sungai karena mengandung bahan-bahan kimia berbahaya [2]

Bahan - bahan kimia pada industri batik berasal dari proses pewarnaan. Pada proses pewarnaan menggunakan bahan pewarna sintetis. Pengrajin lebih memilih menggunakan pewarna sintesis daripada 


\section{Jurnal Pendidikan Sains dan Komputer}

pewarna alami karena warna yang dihasilkan dari pewarna sintesis lebih stabil dan penggunaanya lebih praktis serta lebih mudah mendapatkannya. Sifat pewarna sintesis yang stabil ini membuat pewarna ini lebih sulit dan lebih lama untuk bisa terurai dilingkungan sehingga menjadi polutan dan mengganggu keseimbangan lingkungan perairan. Pada pewarna sintetis mengandung senyawa kimia berupa logam berat. Senyawa logam berat yang terdapat pada buangan industri batik cetak, diduga adalah tembaga $(\mathrm{Cu}), \mathrm{krom}$ $(\mathrm{Cr})$, Timbal $(\mathrm{Pb})$, Mangan (Mn) dan Nikel (Ni). Limbah cair batik selain mengandung senyawa berbahaya juga dapat meningkatkan COD (Chemical Oxygen Demand) dan BOD (Biological Oxygen Demand) air sehingga dapat mengganggu ekosistem perairan [3]

Pengolahan limbah cair industri batik sangatlah penting Oleh karena itu perlu dilakukan pengolahan limbah cair pada industri batik terlebih dahulu sebelum limbah tersebut dibuang ke lingkungan agar memenuhi ketentuan tentang baku mutu air limbah [4]. Berbagai metode telah banyak dilakukan untuk menangani permasalahan limbah cair batik. Salah satu alternatif teknologi yang dapat digunakan untuk mengolah limbah cair adalah metode fitoremidiasi. Fitoremidiasi adalah teknologi untuk memperbaiki lahan dengan menggunakan tanaman [5]. Fitoremidiasi biasanya menggunakan tanaman yang memiliki petumbuhan cepat. Dalam penelitian ini fitoremidiasi menggunakan wetland dibantu tanaman enceng gondok. Tanaman enceng gondok mampu menyerap berbagai zat yang berbahaya yang mencemari perairan seperti logam beracun, cemaran organik, buangan industri, buangan pertanian dan buangan rumah tangga.

Tujuan dari penelitian ini adalah untuk mengetahui kinerja dari tanaman enceng gondok dalam menurunkan kandungan BOD dan COD dalam limbah cair industri batik dengan metode fitoremidiasi sehingga aman dibuang ke lingkungan. Fitoremidiasi menggunakan Constructed wetland merupakan metode yang murah dibandingkan dengan metode-metode yang lain sehingga diharapkan dapat diterapkan pada industri batik. Hal itu dikarenakan permasalahan yang sering terjadi dalam pengolahan limbah cair industri batik yaitu biaya pengolahan limbah yang mahal di industri kecil atau industri rumah tangga. [6]

\section{STUDI LITERATUR}

Fitoremidiasi merupakan tindakan penggunaan tanaman dan bagian-bagiannya untuk mengurangi kontaminasi limbah dan pencemaran lingkungan melalui ex-situ. (menggunakan kolam buatan atau reaktor) maupun in-situ (langsung dilapangan yang terkontaminasi limbah). Fitoremidiasi dapat diterapkan pada limbah anorganik maupun organik dalam bentuk cair, gas, dan padat. beberapa persyaratan tumbuhan sebagai indikator hiperakumulator logam yaitu toleran terhadap logam berat pada konsentrasi tinggi di jaringan akar dan tajuk, tingkat laju penyerapan logam berat yang tinggi dibandingkan tumbuhan lainnya, serta memiliki potensi mentranslokasi dan mengakumulasi logam berat dari akar ke tajuk dengan laju yang tinggi [7].

Salah satu jenis tanaman yang dapat digunakan untuk meremediasi limbah adalah eceng gondok (Eichhornia crassipes). Eceng gondok merupakan gulma air karena petumbuhannya yang begitu cepat. Fitoremidiasi menggunakan tanaman enceng gondok dapat menurunkan kandungan COD dan kandungan $\mathrm{Cu}$ dan $\mathrm{Cr}$ dari limbah cair laboratorium. Efektivitas eceng gondok dalam menurunkan kandungan COD, logam $\mathrm{Cu}$ dan $\mathrm{Cr}$ pada air limbah laboratorium memiliki pola yang cenderung linear atau mengalami peningkatan [8]. Selain tanaman enceng gondok, fitoremidiasi dapat menggunakan celosia plumosa. Fitoremidiasi tanah dengan tanaman Celosia plumosa (Voss) Burv mampu menurunkan kandungan $\mathrm{Hg}$ tanah bahkan untuk tanah sawah dan kebun sudah dibawah nilai ambang batas kandungan logam berat alami pada tanah. Celosia plumosa (Voss) Burv efektif digunakan sebagai agen fitoremidiasi tanah mengandung merkuri (Hg) [9] 
Selain fitoremidiasi, metode untuk pengolahan limbah batik yaitu metode elektrolisis menggunakan elektroda alumunium dengan variasi waktu kontak. Dari hasil penelitian didapatkan Variasi waktu kontak elektrokoagulasi yang digunakan dalam penelitian ini tidak berpengaruh dalam menurunkan COD limbah batik. [10].

Dalam penelitian ini fitoremidiasi menggunakan Constructe wetland. Berdasarkan sistem aliran, ada dua jenis wetland yaitu sistem aliran atas permukaan (Surface Flow Constructed wetland) dan sistem aliran bawah permukaan (Subsurface Flow Constructed wetland/SSF). Constructed wetland dengan aliran atas permukaan adalah sistem constructed wetland yang pengolahannya terjadi di atas permukaan atas air dengan menggunakan tumbuh-tumbuhan yang mengambang. Sedangkan Constructed wetland aliran bawah permukaan (Subsurface Flow Constructed wetlands) merupakan sistem wetland yang bekerja di dasar air dengan menggunakan akar tumbuhan dan media seperti pasir, kerikil dan batuan halus [11].

\section{METODE}

Penelitian ini menggunakan metode eksperimental. Lokasi penelitian pada salah satu industri batik rumahan di Jl. Imogiri, Bantul, Yogyakarta dan di Laboratorium Kampus 2 Institut Teknologi Yogyakarta. Penelitian mengambil variabel bebas adalah waktu fitoremidiasi dan volume limbah cair batik. Sedangkan variabel terikat adalah kandungan COD dan BOD limbah cair batik.

Alat dan Bahan pada penelitian

A. Alat : 1. Gelas takar

\section{Ember}

3. Derigen

4. Bak penampung sementara limbah

5. Bak plastik.

6. Kran air

7. Pipa sambungan

8. Lem pipa paralon

B. Bahan penelitian adalah limbah cair batik dan Tanaman enceng gondok

Tahap-tahap Penelitian

1. Pembuatan Constructed wetland yaitu dengan sistem aliran atas permukaan (Surface Flow Constructed wetland). Wetland dibuat dengan bak plastik yang mempuyai ukuran panjang $=60$ $\mathrm{cm}$, lebar $=35$, dan tinggi $=40 \mathrm{~cm}$. 


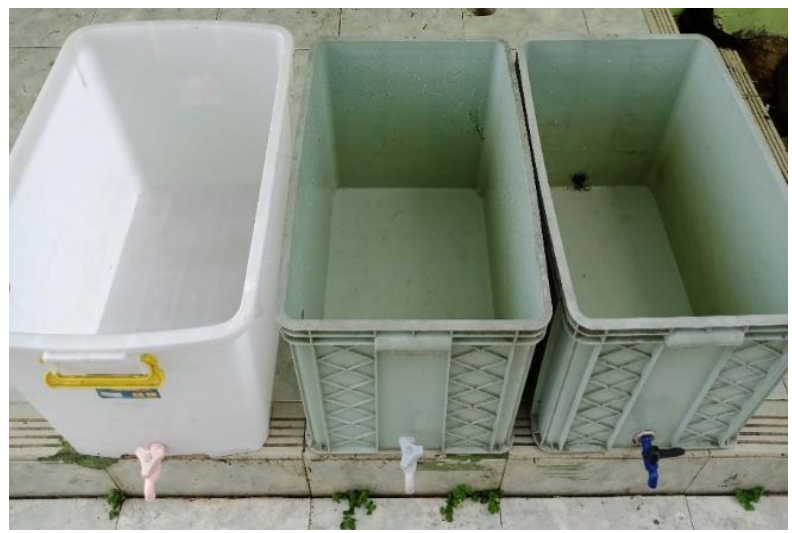

Gambar 1. Constructed wetland

2. Penyesuaian tanaman enceng gondok (aklimatisasi) dengan limbah cair batik dengan takaran sebagai berikut :
a. $25 \%$ Limbah : $75 \%$ Air ( 15 liter air bersih dan 5 liter limbah cair batik )
b. $50 \%$ Limbah : $50 \%$ Air ( 10 liter air bersih dan 10 liter limbah cair batik )
c. $\quad 75 \%$ Limbah : $25 \%$ Air ( 5 liter air bersih dan 15 liter limbah cair batik )
d. $100 \%$ ( 20 liter limbah cair batik )

3. Proses Fitoremidiasi dengan tanaman enceng gondok dengan variasi waktu hari ke 1, 2, 3, 4, 5, 6, dan 7

4. Perhitungan kandungan BOD dan COD limbah cair batik setiap harinya

5. Perhitungan efisiensi penurunan kandungan COD dan BOD pada pengolahan limbah cair batik.

\section{HASIL}

Penelitian diawali dengan pengukuran kandungan COD dan BOD awal limbah cair batik yaitu untuk COD sebesar $2.000 \mathrm{mg} / \mathrm{L}$ dan BOD $1.020 \mathrm{mg} / \mathrm{L}$. Setelah itu pembuatan wetland tipe aliran atas permukaan. Ada 3 wetland dalam penelitian ini, satu wetland untuk control dan dua wetland untuk penelitian serta ulangannya. Sebelum dilakukan proses fitoremidiasi, dilakukan terlebih dahulu proses aklimatisasi atau penyesuaian tanaman enceng gondok dengan limbah cair batik selama dua hari.

Setelah itu, dilakukan pengolahan limbah cair batik dengan metode fitoremidiasi dengan variasi waktu hari ke 1, 2, 3, 4, 5, 6 dan 7. Berikut gambar proses fitoremidiasi ketika wetland sudah terisi limbah cair batik dan tanaman enceng gondok. 


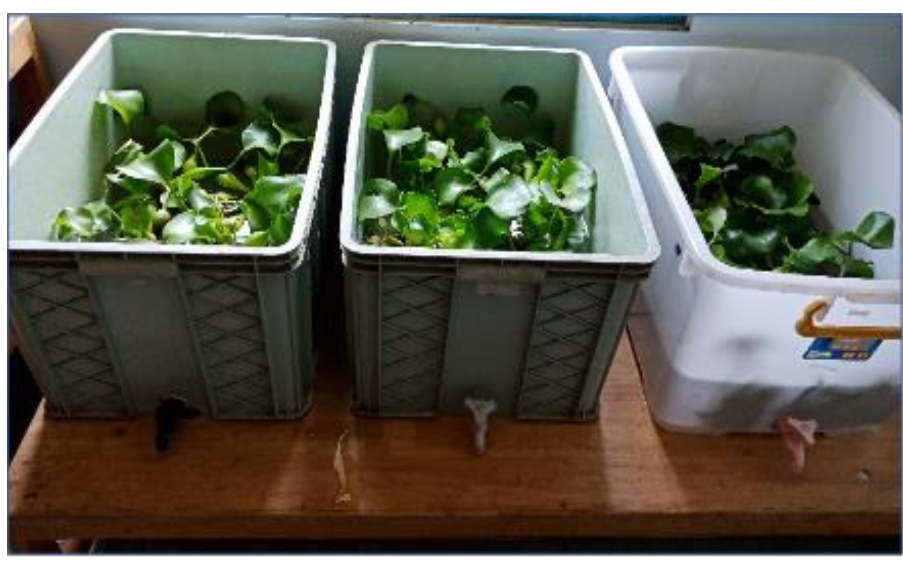

Gambar 2. Fitoremidiasi dengan Constructed wetland

Setiap harinya diambil sampel limbah cair batik untuk dilakukan pengukuran kandungan COD dan BOD. Pengambilan sampel dilakukan melalui kran yang sudah dipasang pada masing-masing constructed wetland. Berikut adalah gambar pengambilan sampel limbah cair batik pada salah satu wetland.

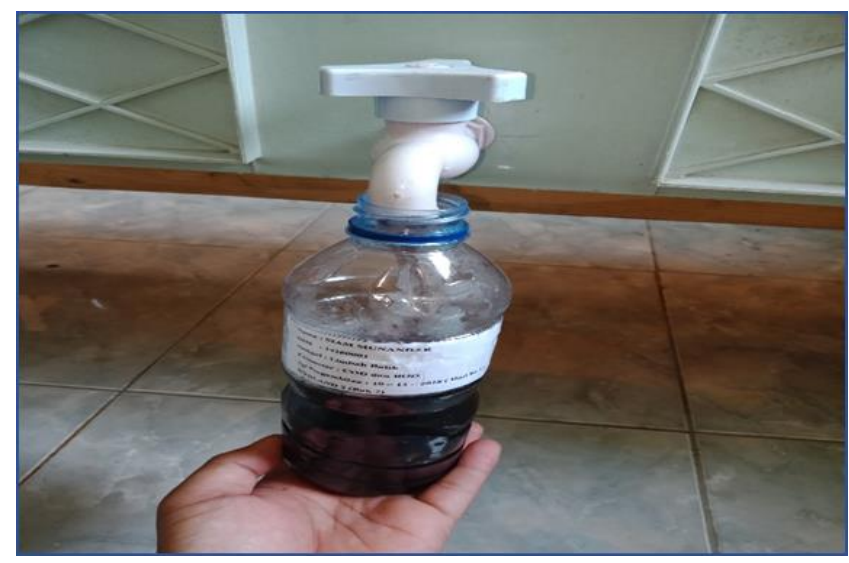

Gambar 3. Pengambilan Sampel Limbah Cair melalui Kran

Hasil pengukuran uji laboratorium kandungan COD dan BOD pada sampel limbah cair batik dengan variasi hari ke 1, 2, 3, 4, 5, 6 dan 7 dapat dilihat pada tabel dibawah ini.

Tabel 1. Kandungan COD dan BOD Limbah Cair Batik

\begin{tabular}{|c|c|c|c|c|c|c|}
\hline \multirow[b]{2}{*}{$\begin{array}{l}\text { Hari } \\
\text { Ke }\end{array}$} & \multicolumn{2}{|c|}{ Kontrol } & \multicolumn{2}{|c|}{ Bak Wetland 1} & \multicolumn{2}{|c|}{ Bak Wetland 2} \\
\hline & $\begin{array}{l}\mathrm{COD} \\
\mathrm{mg} / \mathrm{L}\end{array}$ & $\begin{array}{l}\mathrm{BOD} \\
\mathrm{mg} / \mathrm{L}\end{array}$ & $\begin{array}{l}\text { COD } \\
\mathrm{mg} / \mathrm{L}\end{array}$ & $\begin{array}{l}\text { BOD } \\
\mathrm{mg} / \mathrm{L}\end{array}$ & $\begin{array}{l}\mathrm{COD} \\
\mathrm{mg} / \mathrm{L}\end{array}$ & $\begin{array}{l}\text { BOD } \\
\mathrm{mg} / \mathrm{L}\end{array}$ \\
\hline 1 & 1542,3 & 978,4 & 1030,7 & 564,7 & 1111,5 & 523,8 \\
\hline 2 & 1461,5 & 845,9 & 949,9 & 508,3 & 1003,8 & 510,6 \\
\hline 3 & 1246,1 & 734,2 & 815,3 & 434,8 & 869,1 & 436,9 \\
\hline 4 & 1157,2 & 687,2 & 788,4 & 422,8 & 815,3 & 420,7 \\
\hline 5 & 1030,7 & 612,0 & 788,4 & 402,2 & 815,3 & 405,2 \\
\hline 6 & 1030,7 & 576,9 & 761,4 & 396,7 & 788,4 & 402,2 \\
\hline 7 & 1030,7 & 557,8 & 761,4 & 321,2 & 761,4 & 320,5 \\
\hline
\end{tabular}


Dari tabel terlihat penurunan kandungan COD dan BOD setiap harinya. Berikut grafik penurunan kandungan COD dan BOD pada limbah cair batik.

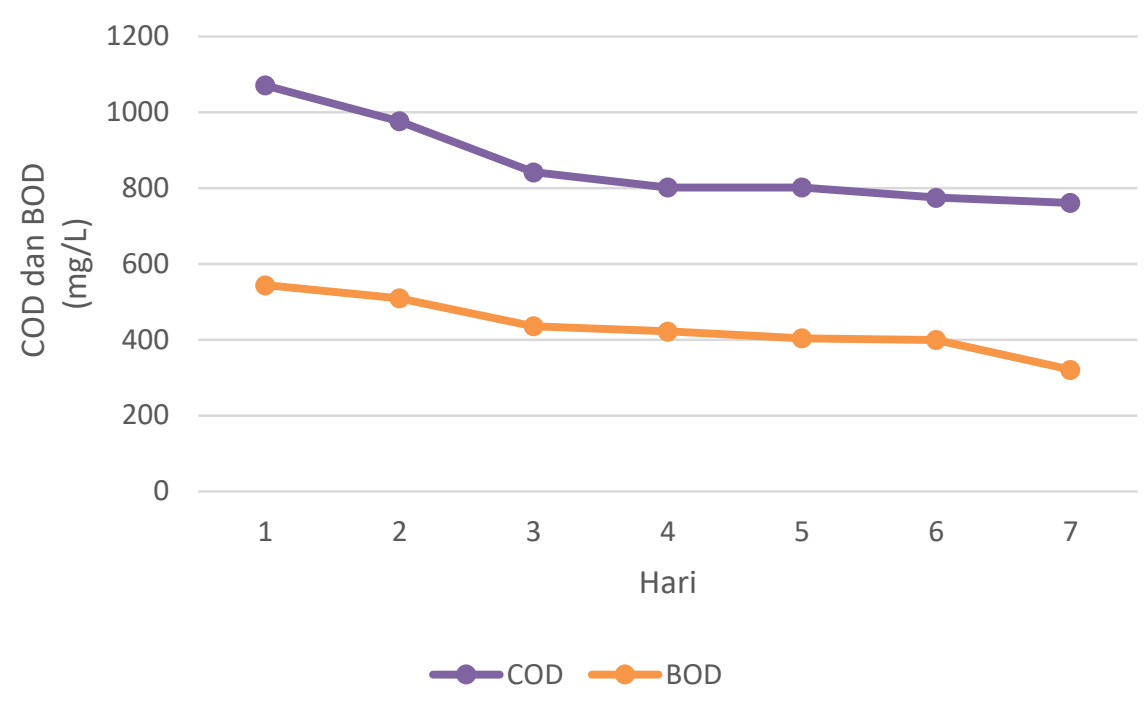

Gambar 4. Grafik Penurunan COD dan BOD Limbah Cair Batik

Dari data uji laboratorium kandungan COD dan BOD limbah cair batik, maka dapat dihitung efisiensi penurunannya. Tabel efisiensi disajikan pada tabel 2 sebagai berikut:

Tabel 2. Penurunan Kandungan COD dan BOD Limbah Cair Batik

\begin{tabular}{|c|c|c|}
\hline Hari Ke & COD & BOD \\
\hline 1 & $46 \%$ & $47 \%$ \\
\hline 2 & $51 \%$ & $50 \%$ \\
\hline 3 & $58 \%$ & $57 \%$ \\
\hline 4 & $60 \%$ & $57 \%$ \\
\hline 5 & $60 \%$ & $60 \%$ \\
\hline 6 & $61 \%$ & $61 \%$ \\
\hline 7 & $62 \%$ & $69 \%$ \\
\hline
\end{tabular}




\section{Jurnal Pendidikan Sains dan Komputer}

\section{Jurnal Pendidikan Sains dan Komputer}

Volume 2, Number 1, February 2022

e-ISSN: 2809-476X

https://doi.org/10.47709/jpsk.v2i1.1340

Enceng gondok merupakan gulma atau tumbuhan pengganggu, namun dengan metode fitoremidiasi justru dapat membantu untuk kepentingan manusia. Fitoremidiasi merupakan jawaban bahwa memanfaatkan enceng gondok berproduktivitas tinggi dalam membantu pengolahan limbah cair [12]. Faktor-faktor yang berpengaruh dalam efektivitas penurunan kandungan COD yakni (a) waktu tinggal padatan atau substrat, (b) kandungan oksigen dan volume lumpur, (c) volume reactor serta (d) jumlah tanaman yang diaplikasikan pada proses fitoremidiasi. Tanaman enceng gondok dalam menyerap polutan organik dalam proses fitoremidiasi dilakukan melalui akarnya. Selanjutnya senyawa organik yang diserap akan masuk ke batang melalui pembuluh pengangkut kemudian menyebar ke seluruh bagian tanaman eceng gondok. Senyawa organik selanjutnya akan mengalami reaksi biologi dan terakumulasi di batang tanaman untuk diteruskan ke daun.

Uji laboratorium pada limbah cair batik sebelum mendapatkan perlakuan menunjukkan kandungan COD sebesar $2.000 \mathrm{mg} / \mathrm{L}$ dan BOD $1.020 \mathrm{mg} / \mathrm{L}$. Kadar yang sangat tinggi, jauh dari baku mutu yang aman untuk dibuang ke lingkungan. Limbah cair batik setelah mendapatkan perlakuan proses fitoremidiasi dengan tanaman enceng gondok mengalami penurunan kandungan COD dan BOD. Dari hasil penelitian terlihat bahwa semakin lama waktu proses fitoremidiasi, maka efektivitas tanaman enceng gondok akan semakin baik. Dari hasil uji laboratorium kandungan COD dan BOD dalam limbah cair batik terjadi penurunan. Pada hari ke 7 kandungan COD sebesar 761,4 mg/L dan BOD sebesar 320,8 mg/L. Dari pengukuran kandungan COD dan BOD limbah cair batik setiap harinya, maka dapat dihitung efisiensi penurunannya. Efisiensi penurunan kandungan COD sebesar 62\% dan BOD 69\%.

Penurunan kandungan COD dan BOD pada limbah cair batik dengan proses fitoremidiasi tersebut karena enceng gondok mampu mengikat bahan-bahan organik dari partikel yang membuat tanaman ini dapat digunakan untuk menjernihkan limbah cair. Enceng gondok memiliki fungsi ekologis sebagai stabilisator suatu perairan karena kemampuannya menetralisir bahan pencemar di perairan [13]

Mekanisme dalam metode fitoremidiasi empat mencakup proses yaitu:

a. Fitoekstraksi adalah penyerapan bahan pencemar oleh akar tanaman.

b. Fitodegradasi adalah metabolisme bahan pencemar di dalam jaringan tanaman oleh enzim

c. Rhizofiltrasi adalah pemanfaatan kemampuan akar tanaman untuk menyerap, mengendapkan, mengakumulasi bahan pencemar dari aliran limbah.

d. Fitostabilisasi adalah kemampuan tanaman dalam mengeluarkan suatu senyawa kimia

e. Fitovolatilisasi terjadi ketika tanaman menyerap bahan pencemar dan melepaskannya ke udara lewat daun dan ada kalanya bahan pencemar mengalami degradasi terlebih dahulu sebelum dilepas lewat daun [14]

Bahan pencemar yang ada di dalam perairan diserap oleh akar eceng gondok dan didistribusikan ke seluruh bagian eceng gondok. Bahan pencemar yang telah diserap oleh akar eceng gondok akan disimpan di bagian tanaman tertentu sehingga tidak mengganggu proses metabolisme eceng gondok [15]. Oleh karena itu, dalam penelitian ini enceng gondok berkerja sangat efektif dalam menyerap kandungan COD dan BOD yang terdapat dalam limbah cair batik. 


\section{KESIMPULAN}

Metode fitoremidiasi dengan Surface Flow Constructed wetland menggunakan tanaman enceng gondok bekerja efektif dalam penurunan kandunganCOD dan BOD pada limbah cair batik. Efisiensi penurunan kandungan COD sebesar 62\% dan BOD 69\%, sehingga metode ini diharapkan dapat diterapkan pada pengrajin atau industri batik.

\section{SARAN}

Untuk penelitian selanjutnya agar mencapai efesiensi penurunan kandungan COD dan BOD limbah cair batik yang maksimal, maka waktu proses fitoremidiasi dapat dilakukan lebih lama.

\section{UCAPAN TERIMAKASIH}

Ucapan terima kasih kepada LPPM Institut Teknologi Yogyakarta yang telah memberikan dukungan dalam penelitian.

\section{REFERENCES}

[1] T. S. N. Ahmed Joko Susilo, "Sistem Pengolahan Limbah Cair Industri Batik di Yogyakarta (Literaure Review)," Prosiding IENACO 2020, 2020.

[2] I. M. S. B. Tri Murniati, "Pengelolaan Limbah Cair Industri Batik dengan Metode Elektrolisis sebagai Upaya Penurunan Tingkat Konsentrasi Logam Berat di Sungai Jenes, Laweyan, Surakarta," Jurnal EKOSAINS, vol. 7 , pp. 77-83, 2015.

[3] I. N. J. d. I. Muhimmatin, "Pengelolaan Limbah Cair Industri Batik menggunakan Mikroorganisme di Kecamatan Cluring Kabupaten Banyuwangi," Warta Pengabdian, vol. 13, no. 3, pp. 106-115, 2019.

[4] L. I. d. M. Triwissara, "Efektivitas Limbah Cair Industri Batik dengan Teknologi Lahan Basah Buatan," Dinamika Kerajinan dan Batik, vol. 35, pp. 53-66, 2018.

[5] R. R. d. R. D. Fatmasari, "Fitoremediasi Tanah Tercemar Logam Timbal (Pb) menggunakan Tanaman Lidah Mertua (Sansevieria trifasciata) dan Jengger Ayam (Celosia plumosa)," AL-ARD: Jurnal Teknik Lingkungan, vol. 3, pp. 62-69, 2018.

[6] S. B. Z. Dian Wahyu, "Pengaruh Jumlah Enceng Gondok (Eichornia crassipes) dan Waktu Tinggal terhadap Penurunan KOnsentrasi COD, BOD dan Warna dalam Limbah Batik".

[7] T. B. H. Z. A. Koko Tampubolon, "Kajian Gulma (Eleusine indica) sebagai Fitoremediator Logam Berat," Jurnal Agrinula: Jurnal Agroteknologi dan Perkebunan, vol. 3, pp. 1-9, 2020. TANAMAN ECENG GONDOK (Eichhornia crassipes) UNTUK MENURUNKAN COD DAN KANDUNGAN $\mathrm{Cu}$ DAN Cr LIMBAH CAIR LABORATORIUM ANALITIK UNIVERSITAS UDAYANA," Cakra Kimia, vol. 5, no. 2, pp. 137-144, 2017.

[9] J. d. M. Alam, "Fitoremidiasi Logam Berat Merkuri (Hg) pada tanah dengan Tanaman Celosia plumosa (Voss) Burv.," Jurnal Biologi Makasar, vol. 1, no. 1, 2016.

[10] T. B. C. A. Mia Nadha Sari, "Varisai Waktu Elektrolisis menggunakan Elektroda Alumunium untuk Menurunkan COD Limbah "Batik Ayu" di Pijenan, Pandak, Bantul," Sanitasi: Jurnal Kesehatan Lingkungan, vol. 8, no. 1, pp. 43-50, 2016.

[11] M. L. R. Y. M. M. K. Ariai Dwi Astuti, "KINERJA SUBSURFACE CONSTRUCTED WETLAND MULTYLAYER FILTRATION TIPE ALIRAN VERTIKAL DENGAN MENGGUNAKAN TANAMAN AKAR WANGI (Vetivera Zozanoides) DALAM PENYISIHAN BOD DAN COD DALAM AIR LIMBAH KANTIN," Jurnal Penelitian dan Karya Ilmiah, vol. 1, no. 2, pp. 91-108, 2016. 
[12] N. A. A. B. N. Nurfadillah, "Fitoremidiasi Limbah Domestik (Detregent) menggunakan Enceng Gondok (Eichorniacrassipes) untuk Mengatasi Pencemaran Lingkungan," Jurnal PENA, vol. 3, no. 2, 2017.

[13] A. S. d. R. A. Gustaman, "Pengendalian Kromium (Cr) yang terdapat di Limbah Batik dengan Metode Fitoremidiasi," Jurnal Kesehatan Masyarakat, Fakultas Ilmu Kesehatan Universitas Siliwangi, vol. 6, no. 3, 2017.

[14] J. C. d. G. A. Moa, "Fitoremediasi Logam Timbal (Pb) menggunakan Tanaman Melati Air (Echinodorus palaefolius) pada Limbah Industri Peleburan Tembaga dan Kuningan," in SEminar Nasional Sains dan Teknologi Terapan III, Surabaya, 2015.

[15] B. S. Sela Putri Herdina, "Efektivitas Lama Kontak Enceng Gondok (Eichhornia) dalam Menurunkan Logam Berat Kromium Heksavalen (Cr6+) pada Limbah Industri Pelapisan Logam," Jurnal Kesehatan Masyarakat, vol. 6, no. 6, pp. 315-324, 2018. 